\title{
A Reflection on Sociology of Education
}

\author{
Sandro Serpa ${ }^{1}$ \\ ${ }^{1}$ Department of Sociology, Faculty of Social and Human Sciences, University of the Azores; Interdisciplinary Centre of \\ Social Sciences-CICS.UAc/CICS.NOVA.UAc, and Interdisciplinary Centre for Childhood and \\ Adolescence-NICA-UAc
}

Correspondence: Sandro Serpa, Department of Sociology, Faculty of Social and Human Sciences, University of the Azores, 9501-801 Ponta Delgada, Portugal. E-mail: sandro.nf.serpa@uac.pt

Received: December 18, 2017

Accepted: January 29, $2018 \quad$ Available online: February 9, 2018

doi:10.11114/ijsss.v6i3.3013

URL: https://doi.org/10.11114/ijsss.v6i3.3013

\begin{abstract}
Following an evident scientific strength of Sociology of Education, especially in the macro-analysis of school phenomena and, in a second moment, in the analysis of school as an organisation, is it possible that, currently, there is a reduction in the centrality of the importance ascribed, at various levels, to this scientific area? This preliminary reflection, which is based on a perspective from Portugal, aims to put forward an insight about Sociology of Education, with all the risks that this kind of analysis entails. Conclusions point to the following relevant dimensions of Sociology of Education: its importance in the definition of several sociological paradigms, considering the (greater or lesser) relevance ascribed to the socialisation process; its specific contribution to the sociological understanding of educational phenomena in the training of future sociologists; and, also, its prospective contribution to the development of Educational Sciences, both in the understanding of educational phenomena in their broadest sense and in dialoguing and participating in discussions on the object of Educational Sciences themselves. So as to achieve this ambition, among other factors, it seems essential that Sociology of Education continues to deepen its knowledge about other educational dimensions beyond school and the phenomena directly connected to it, dialoguing, whenever heuristically relevant, with other scientific areas.
\end{abstract}

Keywords: sociology of education, school, education, socialisation, relevance, potentialities, educational sciences.

Is the modern promise of emancipation, through education, adverse (social, family, cultural...) background conditions and/or repair of pathways that were once irreversible, coupled with the belief in the adherence to education as a key tool to avoid the vulnerabilities and risks of an uncertain world, shaken today?

(Alves, Torres, Dionísio, \& Abrantes, 2016a, pp. xxvii)

\section{Introduction}

Education, in its broadest sense, has been present as a classic key element since the establishment of Sociology as scientific discipline (Abrantes, 2011; Berthelot, 1990; Boarini, 2014; Haetch, 1994; Martins, 2012; Morrow \& Torres, 1997; Queiroz, 2001; Sandoval, 2016), under different approaches. For example, "education as a space for ideological reproduction of the interests of the dominant class (Marx and Engels); as critical integrative institutions for social order (Durkheim); as a source of a new principle of control, as instrumental rationality or bureaucratic domination" (Morrow \& Torres, 1997, p. 24).

In general, the acknowledgement and the academic, social and political status of education and sociology fields may not be very high compared to other scientific areas (Kasapoglu, 2016; Oliveira \& Silva, 2016; Silva \& Alves, 2015). Specifically on Sociology of Education (SE), there is, at times, some confusion between the conceptual definition of education, socialisation and schooling (Boarini, 2014; Vincent, Lahire, \& Thin, 1994), which hampers clarity in the delimitation of SE's object or objects.

There are also clear differences in the objects and, consequently, in the theories used in SE as science (Aníbal, 2009; Beisiegel, 2013; Boarini, 2014; Haetch, 1994; Hart \& Sriprakash, 2017; Loureiro, 2012; Oliveira \& Silva, 2016; Popkewitz, 2013; Sandoval, 2016; Silva \& Alves, 2015; Vasconcellos, 2003; Zago, 2015), where there may be a dimension of fragmentation that reinforces SE's lower visibility, despite its relevance in the understanding of educational (school and non-school) phenomena. 
Especially after World War II, with the valuing of School as institution and, later on, as organisation in the promotion of meritocracy and as a factor of economic development, school inequalities and the result of the processes of democratisation in the massification of school attendance by students in the context of schooling were valued as key objects of analysis in SE (Abrantes, 2011; Aníbal, 2009; Berthelot, 1990; Galarza, 2016; Gomes, 2014; Haetch, 1994; Leal, 2016; Nóvoa, 1995; Queiroz, 2001), given that the educational system integrates students into a common cultural background, but it also differentiates students, by classifying them (Bæck, 2012, p. 665).

Thus, SE was, for a long time and not only in Portugal, basically the/a sociology of School and of the formal education processes. However, SE has never been only a sociology of School at the macro-social analysis level, even occurring an increase in study objects of the meso-social and micro-social type, whether directly related or not to school education (Almeida, 2016; Alves, Torres, Dionísio, \& Abrantes, 2016b, Aníbal, 2009; Ferreira, 2006, Flecha, 2011; Loureiro, 2012, among others). In an up-to-date synthesis:

At the beginning of the $21^{\text {st }}$ century, plurality and diversity characterise Sociology of Education in Portugal and in other countries. In terms of the topics and study objects, a very brief retrospective analysis allows identifying a significant interest in the analysis of educational policies that has accompanied the shifts introduced in the regulation of these policies; the existence of works in the area of multicultural and intercultural education, as well as in the field of gender inequalities and class social inequalities; and it is also possible to identify research on various issues, such as equality of opportunity, social equity or justice in education, and focusing on the different levels of education (from kindergarten to university) and the various ages of life (from childhood to old age) (Silva \& Alves, 2015, p. 24).

At least in Portugal, teachers' training, the inclusion of SE in higher education curricula, and scientific research made it possible to legitimise SE, which gained momentum in the 1970s (for further development and deepening, see Afonso, 2005, 2009; Sebastião, 2017; Silva \& Alves, 2015; Stoer, 2008).

However, after numerous successes, several researchers highlight the SE's progressive lack of visibility in the scientific arena, but mainly in the social and political one (Abrantes \& Amândio, 2014; Aníbal, 2009; Bæck, 2012; Lauder, Brown, \& Halsey, 2009; Mendes, 2009). For example, in Portugal, SE is losing relevance in the educational curriculum of teachers' initial training, despite being one of the vital dimensions of its institutionalisation (Almeida, 2016).

In summary, Pedro Abrantes observed, in 2010, the need to deepen the reflection on SE, and considered, with pertinence, that

[...] sociology of education in Portugal faces, today, unprecedented scientific and professional challenges, such as the relative dependence on educational agendas, the media hegemony of a common-sense discourse on education, the recent restructuring and the drastic reduction in the search for teachers' training programmes, internationalisation requirements and the increasing competition for scientific funding, among others, at a time when it may still not have fully healed some of its classic wounds, in particular the stubborn focus on school, to the detriment of other educational forms and agents, and its ideological and descriptivist drifts, both caused by excess of voluntarism or even normativism, which have sometimes reduced it to a poor relative, whether of the sociological family, or of educational sciences (p. 11).

Notwithstanding several developments since then (see, for example, the proceedings of the Congresses of the Portuguese Sociological Association, available at http://aps.pt/pt/atas-dos-congressos/, as well as the proceedings of the Meetings of the Thematic Section of Sociology of Education of the Portuguese Sociological Association, available at http://aps.pt/pt/atas-encontros-seccoes-tematicas/, which address issues related to SE), this problem seems to us still current.

This preliminary reflection, which is based on a perspective from Portugal, aims to put forward an insight about what may be the relevance and potential of SE today and for the future of Sociology of Education, with all the risks that this kind of analysis entails.

\section{Sociology of Education}

\subsection{Sociology and Sociology of Education}

Sociology, as a scientific area or discipline, as a whole, has its own identity characteristics of scientific and teaching nature (Ferreira \& Serpa, 2017). Specifically on the relationship between Sociology and SE, if SE has been strongly influenced by the paradigms of general Sociology, reflecting, to a certain extent, those dominant ideas, SE also influenced and influences Sociology (Afonso, 2009; Beisiegel, 2013; Ferreira, 2006; Haetch, 1994; Leal, 2016; Lingard \& Thompson, 2017; Sebastião, 2017; Vasconcellos, 2003).

This central importance of SE in the definition of various sociological paradigms considers the greater or lesser 
relevance - but that is always ascribed to the socialisation process (Bæck, 2012). Also because of this, it is very difficult to present a precise definition of SE, which makes it more difficult to clearly distinguish it from other specialised sociologies (Bæck, 2012, p. 659). This, without forgetting the critical function of SE that may influence the reading and analysis of other areas of the social, such as social condition, race, gender and globalisation (Bæck, 2012; Dale, 2010; Lauder et al., 2009; Morrow \& Torres, 1997; Seabra, 2015).

As argued by Vincent et al. (1994) on the importance of SE,

[...] sociology of education is a general condition of all sociology. It allows not forgetting that social beings have a history, a genesis and that they are not beings of anonymous interactions, without a past, etc. Social beings are not "naturally" equipped with interpretative procedures, but by history, by socialisation, and the analysis of socio-historical procedures of interpretation must be one of the objects of sociology (p. 38).

\subsection{Understanding Educational Phenomena}

The specific contribution of SE to the sociological understanding of educational phenomena or others associated with them can be very useful in the sociological training in the most diverse scopes (Flecha, 2011; Gomes, 2014; Haetch, 1994; Leal, 2016; Sandoval, 2016; Seabra, 2015). For example,

The topic of socialisation, of the relationship between attending school and maintaining the social bond, is very current. The criticisms directed at school about its ability to provide young people with skills used in the labour market, about the disregard of the universal value of the knowledge transmitted and about its ability to guarantee the possibilities of social mobility reveal [...] the importance ascribed to this institution (Vasconcellos, 2003, p. 568).

SE, as a specialisation of Sociology as science, has identity specificities of Sociology, some of which can be translated into the following four principles set out in Ferreira and Serpa (2017): the need to permanently use sociological imagination when seeking to seize the social; assume its multi-paradigmatic nature; be receptive to a heuristic inter-disciplinarity; and foster reflexivity. These four principles should be applied in the sociological understanding of educational phenomena, explaining them through social factors (Bæck, 2012; Boarini, 2014; Enguita, 2010; Sandoval, 2016) with critical self-reflection of sociological and educational practice and research (Lima, 2008; Martins, 2012), for which SE may be central (Lauder et al., 2009).

The SE study problems themselves undergo reformulations over time (Ferreira, 2006). Using Costa's (1992) words and applying his argumentative logic of Sociology to SE, it studies and is part of society and its results are integrated into the educational phenomena themselves, which leads to the permanent (re)formulation of the objects that can be studied by SE.

\subsection{Sociology of Education and Educational Sciences}

Finally, SE's potential for the development of Educational Sciences in the understanding of educational phenomena in their broadest and most varied sense seems to be relevant both for education and training professionals, and for various audiences to deepen their educational and pedagogical intentionality, notwithstanding the epistemological, methodological and body-of-knowledge differences (Boarini, 2014; Flecha, 2011; Silva \& Alves, 2015; Szukala, 2012).

However, in the relationship between the Sociological and the Educational Sciences communities, we must bear in mind that these are communities that have differences, insofar that

[...] In Portugal, as in other countries, the development of Sociology of Education has taken place since its beginning, in two institutional contexts: the one of Educational Sciences (closely linked to the training of teachers and other educators) and the one of Sociology (corresponding to the training centred in this scientific area aimed at the training of sociologists) (Silva \& Alves, 2015, p. 18).

This diversity can potentially result in latent tensions between SE integrated into the Portuguese Sociological Association and SE constitutive of the Portuguese Society of Educational Sciences, which does not preclude the existence of a shared matrix (Abrantes, 2004, 2010).

In this process of deepening of a fruitful dialogue on the study of various educational objects, it is important to understand that the relationship between SE and Educational Sciences is indeed very important (Afonso, 2009; Nóvoa, 1995; Silva \& Alves, 2015). Yet, for this relationship to be sufficiently explored, other dimensions of its object must continue to be deepened and developed beyond school and the phenomena directly linked to it (Loureiro, 2012; Seabra, 2015), in a close articulation between Educational Sciences whenever this enhances its heuristic ability to apprehend the object (Boarini, 2014). 


\section{Conclusion}

The previous reflection allows concluding the relevance of SE, materialised, at least, in the following potentialities: its importance in the definition of several sociological paradigms considering the (greater or lesser) relevance ascribed to the socialisation process; its specific contribution to the sociological understanding of educational phenomena in the training of future sociologists; and also its potential contribution to the development of Educational Sciences, both in the understanding of educational phenomena in their broadest sense, recognising its limits, and also by talking and participating in the discussions on the object of Educational Sciences themselves.

In order to achieve this ambition, among other factors, it seems crucial that SE continues to deepen its knowledge about other educational dimensions beyond school and the phenomena directly associated with it (Abrantes, 2010; Abrantes \& Amândio, 2014; Afonso, 2015; Dionísio, Torres, \& Alves, 2017; Loureiro, 2012; Popkewitz, 2013; Seabra, 2015), maintaining dialogue, whenever heuristically relevant, with other scientific areas. This seems to us to be the potential to fulfil the following desideratum: "If a function of sociologists of education is to produce socially useful knowledge, the use of this knowledge in an intervention situation is not less important, thus renewing the analytical ability of the discipline" (Sebastião, 2017, p. 8).

\section{Acknowledgements}

University of the Azores, Interdisciplinary Centre of Social Sciences - CICS.UAc/CICS.NOVA.UAc, UID/SOC/04647/2013, with the financial support of FCT/MEC through national funds and, when applicable, co-financed by FEDER under the PT2020 Partnership Agreement.

\section{References}

Abrantes, P. (2004). Sociologia e Ciências da Educação. A distância entre nós [Sociology and Educational Sciences. The distance between us]. Sociologia, Problemas e Práticas, 45, 117-130. Available at http://www.scielo.gpeari.mctes.pt/pdf/spp/n45/n45a06.pdf

Abrantes, P. (2010). Introdução [Introduction]. In P. Abrantes (Org.), Tendências e controvérsias em Sociologia da Educação [Trends and controversies in Sociology of Education] (pp. 1-12). Lisbon: Editora Mundos Sociais.

Abrantes, P. (2011). Revisitando a teoria da reprodução: Debate teórico e aplicações ao caso português [Revisiting the social reproduction theory: Theoretical debate and application to the Portuguese case]. Análise Social, XLVI(199), 261-281. Available at http://analisesocial.ics.ul.pt/documentos/1317831213W7wZI5xo9B151OS2.pdf

Abrantes, P., \& Amândio, S. (2014). Bernard Lahire e a Sociologia da Educação portuguesa [Bernard Lahire and the Portuguese Sociology of Education]. Educação, Sociedade \& Culturas, 42, 7-25. Available at http://www.fpce.up.pt/ciie/sites/default/files/ESC42_04PedroAbrantes.pdf

Afonso, A. J. (2005). A Sociologia da Educação em Portugal. Elementos para a configuração do "estado da arte" [Sociology of Education in Portugal. Elements for the configuration of the "state of the art"]. In A. Teodoro, \& C. A. Torres (Orgs.), Educação crítica e utopia. Perspectivas para o século XXI [Critical education and utopia. Perspectives for the $21^{\text {st }}$ Century] (pp. 129-158). Porto: Edições Afrontamento.

Afonso, A. J. (2009). Contributos recentes para a Sociologia da Educação em Portugal: Objectos, quadros teóricos e metodologias (2004-2009) [Recent contributions to Sociology of Education in Portugal: Objects, theoretical frameworks and methodologies (2004-2009)]. Revista de Sociología de la Educación (RASE), 2(3), 66-81. Available at https://ojs.uv.es/index.php/RASE/article/download/8690/8233

Afonso, A. J. (2015). Entrevista a... [Interview to...] pp. 7-12. By Leonor Lima Torres. SocEd 14. Newsletter trimestral Secção de Sociologia da Educação, Associação Portuguesa de Sociologia [SocEd 14. Quarterly Newsletter Section of Sociology of Education, Portuguese Sociological Association]. Available at aps.pt/wp-content/uploads/2017/09/newsletter_soced_14.pdf

Almeida, S. (2016). A Sociologia da Educação na formação inicial de professores. Modos de abordagem do conhecimento curricular [Sociology of Education in teachers' initial training. Modes of approach to curricular knowledge]. In M. G. Alves, L. L. Torres, B. Dionísio, \& P. Abrantes (Orgs.), A educação na Europa do Sul. Constrangimentos e desafios em tempos incertos [Education in Southern Europe. Constraints and challenges in uncertain times] (pp. 1137-1151). I $^{a}$ Conferência Ibérica de Sociologia da Educação. Lisbon: Faculdade de Ciências Sociais e Humanas da Universidade Nova de Lisboa.

Alves, M. G., Torres, L. L., Dionísio, B., \& Abrantes, P. (2016a). A Sociologia da Educação na Península Ibérica. Constrangimentos e desafios [Sociology of Education in the Iberian Peninsula. Constraints and challenges]. In M. G. Alves, L. L. Torres, B. Dionísio, \& P. Abrantes (Orgs.), A Educação na Europa do Sul. Constrangimentos e desafios em tempos incertos [Education in Southern Europe. Constraints and challenges in uncertain times] (pp. xxiii-xxxii). 
$I^{a}$ Conferência Ibérica de Sociologia da Educação. Lisbon: Faculdade de Ciências Sociais e Humanas da Universidade Nova de Lisboa.

Alves, M. G., Torres, L. L., Dionísio, B., \& Abrantes, P. (Orgs.). (2016b). A Educação na Europa do Sul. Constrangimentos e desafios em tempos incertos [Education in Southern Europe. Constraints and challenges in uncertain times]. I ${ }^{\text {a }}$ Conferência Ibérica de Sociologia da Educação. Lisbon: Faculdade de Ciências Sociais e Humanas da Universidade Nova de Lisboa.

Aníbal, A. (2009). Um "quase-vazio" a preencher? A Educação "não escolar" como objecto de investigação sociológica em Portugal [A "near-void" to fill in? "Non-school" education as object of sociological research in Portugal]. In Actas do Encontro SocEd2009. Contextos educativos na sociedade contemporânea [Proceedings of the SocEd2009 Meeting. Educational contexts in contemporary society] ( $2^{\text {nd }}$ ed.). Vol. I - Comunicações [Vol. I - Presentations] (pp. 244-259). Lisbon: Secção de Sociologia da Educação da Associação Portuguesa de Sociologia.

Bæck, U. D. K. (2012). Sociology of Education: Outlines towards a diagnosis and thoughts on some major challenges. Scandinavian Journal of Educational Research, 56(6), 659-669. https://doi.org/10.1080/00313831.2011.621137

Beisiegel, C. de R. (2013). Os primeiros tempos da pesquisa em Sociologia da Educação na USP [The early period of research in Sociology of Education at USP]. Educação e Pesquisa, 39(3), 589-607. https://doi.org/10.1590/S1517-97022013005000010

Berthelot, J. M. (1990). Educação (sociologia da) [Education (sociology of)]. In R. Boudon, P. Besnard, M. Cherkaoui, \& B.-P. Lécuyer (Dirs.), Dicionário de sociologia [Dictionary of sociology] (pp. 84-85). Lisbon: Publicações Dom Quixote.

Boarini, M. G. (2014). Análisis epistemológico del curriculum de formación docente: El caso de la sociología de la educación [Epistemological study of teachers' training curriculum: The example of sociology of education). Actualidades Investigativas en Educación, 14(2), 1-20. https://doi.org/10.15517/aie.v14i2.14835

Costa, A. F. da (1992). Sociologia [Sociology]. Lisbon: Difusão Cultural.

Dale, R. (2010). A Sociologia da Educação e o Estado após a globalização [Sociology of Education and the State after globalisation]. Educação \& Sociedade, 31(113), 1099-1120. https://dx.doi.org/10.1590/S0101-73302010000400003

Dionísio, B., Torres, L. L., \& Alves, M. G. (2017). Call da secção temática Sociologia da Educação da Associação Portuguesa de Sociologia para a apresentação de comunicações e/ou posters no X Congresso Português de Sociologia "Na era da pós-verdade"? Esfera pública, cidadania e qualidade da democracia no Portugal contemporâneo [Call of the thematic section Sociology of Education of the Portuguese Sociological Association for the presentation of communications and/or posters at the X Portuguese Congress of Sociology "In the post-truth era"? Public sphere, citizenship and quality of democracy in contemporary Portugal]. Universidade da Beira Interior, July 10-12, 2018. Available at http://aps.pt/wp-content/uploads/2017/11/X-Congresso_Call_Educação_A.pdf

Enguita, M. F. (2010). Algunas cosas que deben cambiar en la Sociología, si no lo han hecho ya [Some things that must be changed in Sociology, if that has not already been done]. Estudos de Sociologia, 15(28), 271-288. Available at http://seer.fclar.unesp.br/estudos/article/download/2560/2180

Ferreira, C. M., \& Serpa, S. (2017). Challenges in the teaching of Sociology in higher education. Contributions to a discussion. Societies, 7(4), 30. https://doi.org/10.3390/soc7040030

Ferreira, R. A. (2006). Sociologia da Educação: Uma análise de suas origens e desenvolvimento a partir de um enfoque da sociologia do conhecimento [Sociology of Education: An analysis of its origins and development from a sociology of knowledge approach]. Revista Lusófona de Educação, 7(7), 105-120. Available at http://revistas.ulusofona.pt/index.php/rleducacao/article/view/805

Flecha, R. (2011). The dialogic sociology of education. International Studies in Sociology of Education, 21(1), 7-20. https://doi.org/10.1080/09620214.2011.543849

Galarza, M. M. (2016). La sociología del sistema de enseñanza de Bourdieu: Reflexiones desde América Latina [Bourdieu's sociology of the educational system: Considerations from Latin America]. Cadernos de Pesquisa, 46(162), 942-964. http://dx.doi.org/10.1590/198053143615

Gomes, A. A. (2014). Educação e sociedade: Perspectivas de análise na sociologia [Education and society: Perspectives of analysis in sociology]. In Actas dos Ateliers do V Congresso Português de Sociologia. Sociedades Contemporâneas: Reflexividade e Acção [Proceedings of the Workshops of the V Portuguese Congress of Sociology. Contemporary Societies: Reflexivity and Action] (pp. 1-6). Atelier: Ciência e Conhecimento [Workshop: Science and Knowledge]. 
Haecht, A. V. (1994). A escola à prova da Sociologia [Sociology-proof school]. Lisbon: Instituto Piaget.

Hart, C. S., \& Sriprakash. A. (2017). Twenty-five years of international studies in Sociology of Education: Looking ahead. International Studies in Sociology of Education, 26(1), 1-2. http://dx.doi.org/10.1080/09620214.2017.1281597

Kasapoglu, A. (2016). Problems with Sociology Education in Turkey on its $100^{\text {th }}$ anniversary. SAGE Open, 6(1), 1-13. https://doi.org/10.1177/2158244016628589

Lauder, H., Brown, P., \& Halsey, A. H. (2009). Sociology of education: A critical history and prospects for the future. Oxford Review of Education, 35(5), 569-585. https://doi.org/10.1080/03054980903216309

Leal, A. Z. (2016). Fracaso escolar y relación con el saber. Elementos de comprensión de las teorías sociológicas de base [School failure and relationship with knowledge. Elements of comprehension of the sociological theories]. Praxis Educativa, 20(2), 13-24. https://doi.org/10.19137/praxiseducativa-2016-200202

Lima, J. Á. de (2008). Em busca da boa escola. Instituições eficazes e sucesso educativo [In search of the good school. Effective institutions and educational success]. Gaia: Fundação Manuel Leão.

Lingard, B., \& Thompson, G. (2017). Doing time in the Sociology of Education. British Journal of Sociology of Education, 38(1), 1-12. https://doi.org/10.1080/01425692.2016.1260854

Loureiro, A. P. F. (2012). "Novos" territórios e agentes educativos em Sociologia da Educação: O caso da educação de adultos ["New" educational territories and agents in Sociology of Education: The case of adult education]. Revista Lusófona de Educação, 20(20), 123-139. Available at http://revistas.ulusofona.pt/index.php/rleducacao/article/view/ $2942 / 2217$

Martins, C. B. (2012). Sociologia e ensino superior: Encontro ou desencontro? [Sociology and higher education: Convergence or divergence?]. Sociologias, 14(29), 100-127. https://doi.org/10.1590/s1517-45222012000100005

Mendes, H. (2009). O eduquês, os seus críticos e a Sociologia da Educação: Como explicar e ultrapassar a "barreira de fogo" [The eduquês, its critics and Sociology of Education: How to explain and overcome the "barrier of fire"]. Actas do Encontro Contextos Educativos na Sociedade Contemporânea. Adenda [Proceedings of the Meeting Educational Contexts in Contemporary Society. Addendum] ( $2^{\text {nd }}$ ed.). Lisbon: Secção de Sociologia da Educação da Associação Portuguesa de Sociologia.

Morrow, R, A., \& Torres, A. T. (1997). Teoria social e educação. Uma crítica das teorias da reprodução social e cultural [Social theory and education. A critique of social and cultural reproduction theories]. Porto: Edições Afrontamento.

Nóvoa, A. (1995). Para uma análise das instituições escolares [For an analysis of school institutions]. In A. Nóvoa (Coord.), As organizações escolares em análise [School organisations under analysis] (pp. 13-43). Lisbon: Publicações Dom Quixote e Instituto de Inovação Educacional.

Oliveira, A, \& Silva, C. F. da (2016). A sociologia e os sociólogos da educação no Brasil [Sociology and sociologists of education in Brazil]. Revista Brasileira de Ciências Sociais. 31(91), 1-15. https://doi.org/10.17666/319108/2016

Popkewitz, T. (2013). The Sociology of Education as the history of the present: Fabrication, difference and abjection. Discourse: Studies in the Cultural Politics of Education, (34)3, 439-456. https://doi.org/10.1080/01596306.2012.717195

Queiroz, J. M. de (2001). L école et ses sociologies [School and its sociologies]. Paris: Nathan Université.

Sandoval, M. C. P. (2016). Veinticinco años de Sociología de la Educación: viejas y 'nuevas' realidades [Twenty-five years of Sociology of Education: Old and 'new' realities]. Espacio Abierto. Cuaderno Venezolano de Sociología, 25(3), 37-48. Available at http://produccioncientificaluz.org/index.php/espacio/article/view/22106/21825

Seabra, T. (2015). Entrevista [Interview]. 8-11. By Mariana Gaio Alves. SocEd 15. Newsletter Secção de Sociologia da Educação - Associação Portuguesa de Sociologia [SocEd 15. Newsletter Section of Sociology of Education Portuguese Sociological Association], aps.pt/wp-content/uploads/2017/09/newsletter_SocEd_15.pdf

Sebastião, J. (2017). 30 Anos de Sociologia da Educação: Altos e baixos de um percurso [30 years of Sociology of Education: Highs and lows of a path]. Jornal de Sociologia da Educação, 0, May. Secção Temática de Sociologia da Educação da Associação Portuguesa de Sociologia [Thematic Section on Sociology of Education of the Portuguese Sociological Association], 1-8. Available at https://jornalsocedu.wordpress.com/30-anos-de-sociologia-da-educacao-altos-e-baixos-de-um-percurso/

Silva, C. F. da, \& Alves, M. G. (2015). O lugar da Sociologia da Educação nas Ciências da Educação: O caso dos programas de mestrado e doutoramento portugueses [The place of Sociology of Education in Educational Sciences: 
The case of the Portuguese master's and $\mathrm{PhD}$ programs]. Política \& Sociedade, 14(31), 17-38. http://dx.doi.org/10.5007/2175-7984.2015v14n31p17

Stoer, S. R. (2008). Notas sobre o desenvolvimento da Sociologia da Educação em Portugal [Notes on the development of Sociology of Education in Portugal]. Educação, Sociedade \& Culturas, 26, 113-132. Available at http://www.fpce.up.pt/ciie/revistaesc/ESC26/26-Notas.pdf

Szukala, A. (2012). Heterogeneous teacher recruitment and social studies didactics: Bringing the Sociology of Education back. Journal of Social Sciences Education, 11(2), 39-59. Available at http://www.jsse.org/index.php/jsse/article/ download/1199/1102

Vasconcellos, M. D. (2003). A Sociologia da Educação na França: Um percurso produtivo [Sociology of Education in France: A productive path]. Educação $e$ Sociedade, 24(83), 553-573. http://dx.doi.org/10.1590/S0101-73302003000200013

Vincent, G., Lahire, B., \& Thin, D. (1994). Sur l'histoire et la théorie de la forme scolaire [On the history and theory of the school form]. In G. Vincent (Dir.), L'éducation prisonnière de la forme scolaire? [Education trapped in the school form?] (pp. 11-48). Lyon: Presses Universitaires de Lyon.

Zago, N. (2015). Um itinerário de pesquisa em Sociologia da Educação: Temas e orientações de trabalhos sobre escolarização nos meios populares [A research itinerary in Sociology of Education: Topics and supervision of research on schooling in low income contexts]. Revista Pedagógica, 17(36), 190-206. https://doi.org/10.22196/rp.v17i36.3157

\section{Copyrights}

Copyright for this article is retained by the author(s), with first publication rights granted to the journal.

This is an open-access article distributed under the terms and conditions of the Creative Commons Attribution license which permits unrestricted use, distribution, and reproduction in any medium, provided the original work is properly cited. 